\title{
Safeguarding Children in the Developing World-Beyond Intra-Organisational Policy and Self-Regulation
}

\author{
Afrooz Kaviani Johnson ${ }^{1, *(D)}$ and Julia Sloth-Nielsen ${ }^{2, *}$ \\ 1 Department of Child Law, University of Leiden, 2311 Leiden, The Netherlands \\ 2 Department of Public Law and Jurisprudence, University of the Western Cape, Bellville, \\ Western Cape 7535, South Africa \\ * Correspondence: a.kaviani.johnson@law.leidenuniv.nl (A.K.J.); jsloth-nielsen@uwc.ac.za (J.S.-N.)
}

Received: 29 April 2020; Accepted: 29 May 2020; Published: 8 June 2020

\begin{abstract}
Safeguarding in the context of development and humanitarian assistance has received heightened international attention since 2018. Emerging literature has not yet investigated the extent to which responses are evolving in the best interests of the child, in line with the treaty-based rights of children. This article makes a unique contribution to scholarship by applying a child rights lens to safeguarding efforts in the aid sector with a focus on the least developed countries in Africa. The article first reviews the safeguarding landscape-providing a snapshot of self-regulatory and standard setting initiatives by non-government organisations (NGOs) and bilateral government donors. Next, the article examines the relevant standards in the Convention on the Rights of the Child and the African Charter on the Rights and Welfare of the Child and respective Committee observations to enrich the safeguarding discussion. Finally, the article discusses key dilemmas and remaining challenges for safeguarding children in the developing world. The article suggests that a rights-based approach provides for a more nuanced and contextualised response, avoiding the temptation of 'tick-box' exercises driven by reputational management and 'programming siloes' imposed by humanitarian and development actors. To support sustained and consistent progress, efforts should go beyond intra-organisational policy and sectoral self-regulation. Child rights law monitoring mechanisms can be leveraged to encourage effective government oversight of NGOs in contact with children, as part of national frameworks for child protection. Donor governments should also consider and increase investment in national and local child protection systems to address risk factors to child abuse and ensure appropriate responses for any child that experiences harm.
\end{abstract}

Keywords: safeguarding; child protection; child abuse; risk to children; sustainable development goals; convention on the rights of the child; African charter on the rights and welfare of the child; non-government organisations

\section{Introduction}

The global community has less than a decade to achieve the Agenda for Sustainable Development and Sustainable Development Goals (SDGs). Agenda 2030 envisages a "world which invests in its children and in which every child grows up free from violence and exploitation" (United Nations General Assembly 2015, para. 8) and expressly includes several targets to end all forms of violence against children. ${ }^{1}$ Unlike the preceding Millennium Development Goals, Agenda 2030 is grounded in

1 Including to eliminate all forms of violence against all women and girls (target 5.2), to take immediate and effective measures to secure the prohibition and elimination of the worst forms of child labour, including recruitment and use of child soldiers, 
human rights standards and requires that the goals "be implemented in a manner that is consistent with the rights and obligations of States under international law" (United Nations General Assembly 2015, para. 18).

Those obligations relating to children's right to be protected from violence are articulated under several international instruments - most notably the Convention on the Rights of the Child and the Optional Protocol to the Convention on the Rights of the Child on the sale of children, child prostitution and child pornography. The Convention has near universal ratification, except for the United States of America (US). Most African countries have ratified the Optional Protocol (United Nations Human Rights Office of the High Commissioner 2020). In the regional context, the African Charter on the Rights and Welfare of the Child has comparative articles expounding children's right to be protected from violence. Regional policy frameworks include the African Union Agenda 2063 and Africa's Agenda for Children 2040 (African Committee of Experts on the Rights and Welfare of the Child 2018).

Despite the global and regional aspirations, high rates of violence against children persist. There is insufficient investment in tackling root causes and drivers of violence, as well as in those specialised services to support children and families affected by violence. In much of Africa, social welfare and child protection services are largely delivered by non-State actors including non-government organisations (NGOs), faith-based organisations, and community actors. Formal legal systems do not function optimally. In many cases, this enables a culture of impunity for perpetrators (Csáky 2008, p. 20). Not surprisingly, in the least developed countries, cases of child abuse and exploitation perpetrated by those meant to 'help' communities are met with heightened public outrage. This outrage ripples across the Global North in cases which implicate 'Western' offenders, international NGOs and Official Development Assistance.

In early 2018, allegations of the sexual exploitation of women and girls by a senior Oxfam staff member following the 2010 earthquake in Haiti made global headlines (BBC 2018). The revelations triggered critical introspection within the humanitarian and development sector and a flurry of consequent activity. Like the reactions following the 2002 West African 'sex-for-food' scandal (United Nations High Commissioner for Refugees \& Save the Children UK 2002), several significant policy commitments on 'safeguarding' emerged, largely from the components of the 'aid chain' headquartered in the Global North. Scholarly engagement with the concept of safeguarding is just emerging (Sandvik 2019 , p. 2), and literature has not yet explored the extent to which responses are evolving in the best interests of the child, in line with the treaty-based rights of children. Although the Oxfam investigations were reportedly unable to substantiate the allegations concerning girls (Charity Commission for England and Wales 2019), the risks to children arising from development and humanitarian activity are well known to child protection practitioners and documented by Csáky (2008), amongst others.

This article makes a unique contribution by applying a child rights lens to safeguarding efforts in the aid sector, with a focus on the least developed countries in Africa, from a view in the developing world. The article examines child safeguarding within the public international law framework, taking a child rights, legal theory-based approach, and drawing on international human rights standards and norms set out in the Convention on the Rights of the Child and other relevant instruments. The article also draws on the observations of the Committee on the Rights of the Child and the African Committee of Experts on the Rights and Welfare of the Child and existing legal academic scholarship relating to children's rights. The methodology necessarily employed both legal and interdisciplinary research. The sources reviewed and analysed were identified through comprehensive desk research via databases, journal tracking and review of grey literature, including research reports, conference proceedings, and government documents on thematic areas of child abuse and exploitation, child safeguarding, safeguarding, institutional child abuse, child protection and abuse of power in development and

and, by 2025, end child labour in all its forms (target 8.7) and to end abuse, exploitation, trafficking and all forms of violence against and torture of children (target 16.2). 
humanitarian contexts, with a focus on Africa. The article is also informed by the authors' professional experience in child rights and protection in Africa and internationally. The article first reviews the safeguarding landscape-providing a snapshot of self-regulatory and standard setting initiatives by the sector over the last three decades. Next, the article examines the relevant standards in the Convention on the Rights of the Child and the African Charter on the Rights and Welfare of the Child and respective Committee observations to enrich the safeguarding discussion. Finally, the article discusses key dilemmas and remaining challenges for safeguarding children in the developing world.

The article suggests that a rights-based approach provides for a more nuanced and contextualised response, avoiding the temptation of 'tick-box' exercises driven by reputational management and 'programming siloes' imposed by humanitarian and development actors. To support sustained and consistent progress, efforts should go beyond intra-organisational policy and sectoral self-regulation. Child rights law monitoring mechanisms can be leveraged to encourage effective government oversight of NGOs in contact with children, as part of national frameworks for child protection. While safeguarding discourse in certain policy arenas has focused on sexual exploitation and abuse, an especially egregious violation of children's rights, a rights-based approach should consider the various intersections between humanitarian and development activity and children's treaty-based rights. This should encompass all risks and harms including those arising in the digital era. Intra-organisational efforts are interlinked and dependent on local and national systems. As such, donor governments should consider and increase investment in child protection systems to address risk factors to child abuse and ensure appropriate responses for any child that experiences harm. At the time of writing, countries in Africa are beginning to deal with secondary impacts of the COVID-19 pandemic and, more than ever, robust social services are required to protect the most vulnerable children.

\section{The Safeguarding Landscape-Evolving Self-Regulation and Standard Setting}

Safeguarding means different things to different people (Sandvik 2019, p. 4). Until relatively recently, the term was almost exclusively used in the United Kingdom (UK) as a legal definition applied to vulnerable adults and children (HM Government 2018; UK Department for International Development 2019, p. 23). In the context of aid, the term has evolved to focus on the organisational 'duty of care' and responsibility to 'do no harm'. The term remains poorly understood in the Global South (Walker-Simpson 2017, p. 254). While different organisations use different terminologies (Sandvik 2019, p. 2), the broader issue of NGO accountability to the people they serve can be positioned within a context of at least three decades of evolving NGO self-regulation and standard setting. This section provides a snapshot of these efforts.

\subsection{Self-Regulatory and Standard Setting Initiatives and the West Africa 'Sex-for-Food' Scandal}

The demand for humanitarian relief following the end of the Cold War saw a proliferation of new organisations that were often "inexperienced and unprofessional" (Zarnegar Deloffre 2016, p. 729). Attention was drawn to NGO accountability and the lack of professional standards following a series of "problematic" emergency relief operations, particularly in Ethiopia, Somalia, and Rwanda (Zarnegar Deloffre 2016, p. 729). Industry-wide standards emerged for NGOs to distinguish themselves from "low-quality" organisations (Zarnegar Deloffre 2016, p. 729). These standards included the Sphere Humanitarian Charter and Minimum Standards, People in Aid Code of Conduct, and the Code of Conduct for International Red Cross and Red Crescent Movement (Sandvik 2019, p. 2). The Humanitarian Accountability Project was established in 2000, with the aim of piloting an international aid ombudsman (Hilhorst et al. 2018, p. 15).

The issue of child exploitation perpetrated by humanitarian workers first came to global attention in 2002, with the West African 'sex-for-food' scandal. A United Nations High Commissioner for Refugees (UNHCR) and Save the Children report implicated 67 personnel from 42 agencies in Liberia, Sierra Leone and Guinea in the sexual exploitation of refugee children (United Nations High Commissioner for Refugees \& Save the Children UK 2002). The revelations precipitated the development of several 
policies, codes and procedures by the UN and civil society. While not the focus of this article, those key UN developments deserve mention as they have also guided the policies and standards of NGOs. These include the establishment of the Inter-Agency Standing Committee on sexual exploitation and abuse and subsequent guidance for protection from and response to sexual exploitation and abuse (Inter-Agency Standing Committee n.d.), the UN General Assembly resolution on the investigation into sexual exploitation of refugees by aid workers in West Africa (United Nations General Assembly 2003), and the issuance of a global policy in the form of the Secretary-General's Bulletin, Special measures for protection from sexual exploitation and sexual abuse (United Nations Secretariat 2003). Importantly the Bulletin provides that sexual activity with children (persons under the age of 18) is prohibited regardless of the age of majority or age of consent locally, and that mistaken belief in the age of a child is not a defence. The safeguarding policies of many NGOs and bilateral donors mirror these standards.

Around the same time, a coalition of humanitarian and development NGOs in the UK came together to establish the Keeping Children Safe coalition. The first version of the Child Safeguarding Standards was launched in 2002. The standards call for organisations to: (i) develop a policy describing commitment to prevent and respond appropriately to harm to children; (ii) place clear responsibilities and expectations on staff and associates and support them to understand and act in line with these; (iii) create a child-safe environment through implementing child safeguarding procedures across the organisation; and (iv) monitor and review safeguarding measures (Keeping Children Safe 2014, p. 10). Keeping Children Safe has evolved into an independent NGO, which also provides consultancy services to organisations to improve child safeguarding internationally (Keeping Children Safe n.d.).

The protection of beneficiaries (adults and children) from sexual exploitation and abuse was also integrated into the work of the Humanitarian Accountability Project (HAP) and its successor Core Humanitarian Standards Alliance. ${ }^{2}$ The Core Humanitarian Standard on Quality and Accountability sets out nine commitments that organisations and individuals involved in humanitarian response can use to improve the quality and effectiveness of the assistance they provide. The Core Humanitarian Guidance Note draws attention to the issue in five of the nine commitments. Commitment 1 (to ensure assistance appropriate to needs) calls for consideration of protection concerns, such as preventing sexual exploitation and violence. Commitment 3 (to ensure no negative impacts) recognises the "high value of aid resources and the powerful position of aid workers" and requires identification and timely action upon unintended negative effects including sexual exploitation and abuse by staff. Commitment 4 (to provide access to information and participation) explains that people may be vulnerable to exploitation and abuse (including sexual abuse) if they do not know their entitlements, the standards of behavior for humanitarian workers, and how to make a complaint. A child safeguarding policy is expressly recommended under Commitment 5 (complaints mechanisms). As part of guidance to monitor organisational responsibilities, Commitment 8 (well-managed staff and volunteers) includes a question on whether all staff and contractors are required to sign a code of conduct that covers the prevention of sexual exploitation and abuse (Core Humanitarian Standard (CHS)).

On a national level in the Global North, NGO umbrella bodies (such as the Australian Council for International Development in Australia, Bond in the UK, and InterAction in the US) championed codes of conduct, and accreditation, risk management and contracting arrangements of some governments were utilised to enforce standards (Humanitarian Advisory Group 2018). The Australian Government was the first bilateral donor to implement child protection standards for staff and funded partners under its Child Protection Policy, introduced in 2008 (AusAID 2013). The mandatory child protection standards follow five key principles: zero tolerance of child exploitation and abuse; recognition of the best interests of the child; sharing responsibility for child protection; procedural fairness; and a risk management approach to reduce the risks of child exploitation and abuse with aid activities.

2 HAP joined with Sphere and People in Aid to become part of the Joint Standards Initiative. In December 2014, the Core Humanitarian Standard (CHS) was launched in Copenhagen. In 2015, HAP and People in Aid merged to form the CHS Alliance (Hilhorst et al. 2018, p. 15). 
The United States Agency for International Development (USAID) also introduced Child Safeguarding Standards to cover "all activities intended to prevent and respond to abuse, exploitation, or neglect by USAID personnel, contractors, and recipients or as a result of USAID-supported programming" (USAID 2015). The standards complement the USAID Counter Trafficking in Persons Code of Conduct. On an organisational level, policies and standards on child protection/safeguarding, gender equality, and codes of conduct were developed and implemented in many aid organisations to varying degrees.

\subsection{New and Emerging Initiatives_Post Oxfam, \#MeToo and \#AidToo}

In February 2018, The Times newspaper published a front-page article headlined 'Top Oxfam staff paid Haiti survivors for sex', which alleged that Oxfam covered up claims that senior staff working in Haiti following the 2010 earthquake used prostitutes, some of whom may have been under 18 (BBC 2018). Around the same time, \#MeToo and then \#AidToo revelations snowballed. ${ }^{3}$ These included accounts of rape, assault, and harassment in the workplace that were seen to be badly handled, denied or concealed by NGOs (Parker 2018b). The parameters of safeguarding in the aid sector thus expanded to include workplace relations and harassment within organisations. The rationale was that both were enabled by power imbalances, especially gender inequality (UK Department for International Development 2018b, p. 15).

In March 2018, the UK Parliamentary International Development Committee launched an inquiry on sexual exploitation and abuse in the aid sector (UK Parliament 2018). In its final report, the committee was highly critical of the failure of the international system to tackle these abuses, and accused the sector generally of "complacency, verging on complicity" (House of Commons, International Development Committee 2018, p. 29). The report made a number of recommendations, largely directed at the UK Department for International Development (DFID), including the creation of an international register of aid workers to function "as one barrier to sexual predators seeking to enter the international aid profession", and the establishment of an independent aid ombudsman "to provide a right to appeal, an avenue through which those who have suffered can seek justice by other means"(House of Commons, International Development Committee 2018, pp. 79, 64). The committee encouraged DFID to use a forthcoming 'Safeguarding Summit' to secure commitments from across the sector to move the measures forward.

The Safeguarding Summit, convened by DFID in October 2018, brought together over 500 delegates including government donors (representing 90 percent of global Official Development Assistance), the UN, international financial institutions, UK NGOs, and UK private sector supply partners (Commitments Made by Donors to Tackle Sexual Exploitation and Abuse and Sexual Harassment in the International Aid Sector). The summit faced some controversy and criticism, including the lack of diversity in the speakers and near absence of voices from the Global South (Donovan 2018; Parker 2018b). At the summit, the UK International Development Secretary launched several initiatives including a DFID scheme to work with Interpol to vet aid workers against criminal records, a Misconduct Disclosure Scheme to allow employers to check for previous misconduct linked to sexual abuse and exploitation, and a Humanitarian Passport Scheme to prove an individual's identity and vetting status (UK Department for International Development 2018a).

Promising commitments were made by all constituencies at the conclusion of the summit. This included pledges by NGOs to address organisational culture and improve existing processes for safeguarding (Bond 2019). Perhaps most significant were the commitments made by 22 donors ${ }^{4}$

3 The \#MeToo movement started over a decade ago in the US as a grassroots effort to show support for survivors of sexual violence, particularly young women of colour from low socio-economic backgrounds, and gained near global prominence from 2017 when the \#MeToo hashtag went viral. Women in the international aid sector used the hashtag \#AidToo to bring attention to sexual violence within the sector (Gillespie et al. 2019).

4 Australia, Austria, Belgium (Ministry of Development Cooperation), Canada, Denmark, Finland, France (Ministry for Europe and Foreign Affairs of France), Germany, Iceland, Ireland, Italy, Japan (Ministry of Foreign Affairs of Japan), Luxembourg (Ministry of Foreign and European Affairs), Mexico (AMEXID), the Netherlands (Ministry for Foreign Trade 
designed to bring about four "long-term strategic shifts", namely: (i) ensuring support for survivors, victims and whistle-blowers, enhancing accountability and transparency, strengthening reporting and tackling impunity; (ii) incentivising cultural change through strong leadership, organisational accountability and better human resource processes; (iii) agreeing minimum standards and ensuring donors and their partners meet them; and (iv) strengthening organisational capacity and capability across the international aid sector, including building the capability of implementing partners to meet the minimum standards (Commitments Made by Donors to Tackle Sexual Exploitation and Abuse and Sexual Harassment in the International Aid Sector).

Subsequently, 30 members $^{5}$ of the Organisation for Economic Cooperation and Development (OECD) adopted the Development Assistance Committee (DAC) Recommendation on Ending Sexual Exploitation, Abuse, and Harassment in Development Co-operation and Humanitarian Assistance in July 2019 (OECD Development Assistance Committee 2019) ${ }^{6}$ This is the first international instrument to address sexual exploitation, abuse, and harassment across the sector. The preamble of the DAC Recommendation recognises the Inter-Agency Standing Committee's Principles and Minimum Operating Standards on Prevention of Sexual Exploitation and Abuse and the Core Humanitarian Standard on Quality and Accountability as essential international standards. The rights and needs of children come out expressly in the preamble of the DAC Recommendation, with the recognition "that child survivors require particular attention to ensure their safety, protection, and well-being". Paragraph 2(d) of the DAC Recommendation also calls for the strengthening of "existing local services and networks and coordination with gender-based violence and child-protection services".

The Dutch Ministry of Foreign Affairs took forward a scoping study to assess whether there is a need for an aid ombudsman and, if so, how it might function and fit with existing governance mechanisms in the sector. The study, published in September 2018, found strong consensus on the need for an ombudsman mechanism in the sector to provide independent recourse for complainants (Hilhorst et al. 2018). While the ombudsman concept has reportedly since been abandoned by the UK Government (Edwards 2019), other initiatives have progressed. For example, the Misconduct Disclosure Scheme to check for previous misconduct linked to sexual exploitation, abuse or harassment is operating. As of October 2019, 10 people have reportedly been prevented from being re-hired (UK Department for International Development 2019, p. 4), and 15 organisations are using the scheme (Steering Committee for Humanitarian Response, Misconduct Disclosure Scheme). Some donors are also working with the Core Humanitarian Standards Alliance and Humanitarian Quality Assurance Initiative to strengthen verification options for CHS quality assurance and to develop models that better reflect the needs of organisations (UK Department for International Development 2019, p. 13).

\section{International and Regional Child Rights Frameworks to Guide Safeguarding}

There are clear intersections between violence against women and violence against children and strong arguments for improved convergence in programming (Guedes et al. 2016). However, there is also a need for a dedicated discussion on the specific rights and needs of children, which has been somewhat diluted in some policy arenas. While the Convention on the Rights of the Child $(\mathrm{CRC})$ is referred to cursorily in the safeguarding discussion as a reference point for guidance and

and Development Cooperation), New Zealand (Ministry of Foreign Affairs and Trade), Norway, Spain, Sweden, Switzerland, United Kingdom (including the Scottish Government), and the United States of America (U.S Agency for International Development).

5 Australia, Austria, Belgium, Canada, Czech Republic, Denmark, Finland, France, Germany, Greece, Hungary, Iceland, Ireland, Italy, Japan, Korea, Luxembourg, Netherlands, New Zealand, Norway, Poland, Portugal, Slovak Republic, Slovenia, Spain, Sweden, Switzerland, United Kingdom, United States and the European Union.

6 The Recommendation encompasses six pillars: (i) policies, professional conduct standards, organisational change and leadership; (ii) survivor/victim-centred response and support mechanisms; (iii) organisational reporting, response systems and procedures; (iv) training, awareness raising and communication; (v) international coordination; and (vi) monitoring, evaluation, shared learning and reporting. 
minimum standards, mentions are largely aspirational and transitory. This section explores how child rights standards and existing monitoring mechanisms for human rights law could support a more sustainable and consistent effort to ensure children's protection in the context of humanitarian and development activity.

\subsection{Relevant Treaties and Articles for Safeguarding Children}

The CRC is the primary instrument relating to children's right to protection from violence. ${ }^{7}$ In the regional context, the African Charter on the Rights and Welfare of the Child (ACRWC) has comparative articles setting out children's rights to protection. The focus on children's rights is important in framing the response to the issue and rejects approaches where children are characterised only as "objects in need of assistance rather than as subjects with rights" (Tobin and Seow 2019, p. 1312). The child rights approach also recognizes that children are human beings in their own right and not 'adults in waiting' ${ }^{8}$

The monitoring of State party compliance with obligations under the CRC involves external oversight by the Committee on the Rights of the Child (the CRC Committee). African states are also subject to oversight by the African Committee of Experts on the Rights and Welfare of the Child (the African Committee) with regards to compliance with the ACRWC. State parties are required to report periodically to the Committees and Committees thereafter issue Concluding Observations and Recommendations. Although these observations and recommendations impose no legal obligation, they are often an agenda for action and have had an "intensifying or catalyst effect" to support political and legal processes in countries (Sloth-Nielsen 2018, pp. 14-16).

While safeguarding discourse in certain policy arenas has focused on sexual exploitation and abuse, an especially egregious violation of children's rights, a rights-based approach should consider the various intersections between humanitarian and development activity and children's treaty-based rights. This should encompass all risks and harms. By way of example, the 2002 UNHCR and Save the Children report also highlighted other forms of exploitation such as child labour. An adolescent boy in Sierra Leonne is quoted as saying: "I have no father and no mother and there are jobs that I am being made to do like washing underpants in exchange for food which I do because I have no parents. I wish I had my parents because I do not have any support and I am exposed to so much abuse" (United Nations High Commissioner for Refugees \& Save the Children UK 2002, p. 43). Issues of safeguarding would fall primarily under the CRC theme (or 'cluster') related to violence against children. ${ }^{9}$ The CRC Committee (United Nations Committee on the Rights of the Child 2015, para. 30) explains that this cluster includes abuse and neglect (Article 19), ${ }^{10}$ measures to prohibit and eliminate all forms of harmful practices, including, but not limited to, female genital mutilation and early and forced marriages (Article 24), sexual exploitation and sexual abuse (Article 34), ${ }^{11}$ the right not to be subjected to torture or other cruel, inhuman, or degrading treatment or punishment, including corporal punishment (Articles 37 (a) and 28), measures to promote the physical and psychological recovery and social reintegration of child victims (Article 39), and the availability of helplines for children. Other forms of exploitation, including child labour, are to be reported under the special protection measures

7 Other international instruments include the Protocol to Prevent, Suppress and Punish Human Trafficking in Persons, especially Women and Children, supplementing the Convention against Transnational Organised Crime, the Convention concerning the Prohibition and Immediate Action for the Elimination of the Worst Forms of Child Labour and the Optional Protocol to the Convention on the Rights of the Child on the Sale of Children, Child Prostitution and Child Pornography. The relationship between the instruments should be understood as complementary (Tobin and Seow 2019, p. 1314).

8 The authors are grateful to an anonymous reviewer for emphasizing this point.

9 In 2015, the Committee on the Rights of the Child revised the guidelines for periodic reports to reflect the new cluster on violence against children and to update references to general comments (United Nations Committee on the Rights of the Child 2015).

10 Article 19 is regarded as "the core provision for discussions and strategies to address and eliminate all forms of violence in the context of the Convention more broadly" ((United Nations Committee on the Rights of the Child 2011, para. 7(a))).

11 In contrast to Article 19, Article 34 imposts a blanket obligation on states to protect children from sexual abuse and exploitation irrespective of whether they are in the care of their parents (Tobin and Seow 2019, p. 1312). 
cluster (United Nations Committee on the Rights of the Child 2015, para. 40). The relevant articles in the ACRWC include Articles 14 (child labour), 16 (child abuse and torture), 21 (harmful social and cultural practices), 22 (armed conflicts) and 27 (sexual exploitation) in particular. In its General Comment No. 5 on State Party Obligations under the African Charter on the Rights and Welfare of the Child (Article 1) and Systems Strengthening for Child Protection, the African Committee elaborates on the measures required to improve implementation of the ACRWC and in particular calls for States to States "to adopt a holistic approach" to realise children's right to survival, development and protection provided by Article 5 of the ACRWC. The African Committee explains that this is enabled by adopting a systems-strengthening approach to child protection (African Committee of Experts on the Rights and Welfare of the Child 2018, p. 12). A systems-strengthening approach would include both formal and informal local contexts around the child (African Committee of Experts on the Rights and Welfare of the Child 2018, p. 33).

\subsection{Domestic Implementation and the Role of the International Community}

The observations of the CRC Committee are useful to articulate the respective responsibilities of developing vis-à-vis donor countries. The CRC Committee is cognisant of the different starting points of State parties in implementing the CRC and obligations relating to protection of children from violence. The CRC Committee acknowledges that protecting children from all forms of violence is highly challenging in most countries and that States parties are designing and implementing measures from "very different starting points" with respect to existing legal, institutional and service infrastructures, cultural customs and professional competencies, and levels of resources (United Nations Committee on the Rights of the Child 2011, para. 70).

While recognising different starting points, the CRC Committee highlights that the right to protection from all forms of violence outlined in Article 19 is a civil right and freedom. As such, in applying Article 4 of the CRC (taking all appropriate legislative, administrative, and other measures for the implementation of the rights), implementation of Article 19 is "an immediate and unqualified obligation" of States parties (United Nations Committee on the Rights of the Child 2011, para. 65). This means that in spite of economic circumstances, States are required to undertake all possible measures towards the realisation of children's rights, paying special attention to the most disadvantaged and using available resources "to the maximum extent" (United Nations Committee on the Rights of the Child 2011, para. 65). The African Committee likewise emphasises that "whatever their economic circumstances, States Parties are required to undertake all possible positive measures towards the realisation of the rights of the child" and to pay "special attention to the most disadvantaged and marginalised groups" (African Committee of Experts on the Rights and Welfare of the Child 2018, p. 6). On child protection specifically, the African Committee notes "State Party spending on child protection and systems strengthening is far too low, and lacks visibility in government budgets" (African Committee of Experts on the Rights and Welfare of the Child 2018, p. 36).

The CRC Committee is explicit that "resource constraints cannot provide a justification for a State party's failure to take any, or enough, of the measures that are required for child protection" taking into consideration State parties' obligations under Articles 4 and 19 (United Nations Committee on the Rights of the Child 2011, para. 73). While acknowledging fiscal realities in Africa, the African Committee states that the ACRWC standards "were set intentionally" and "do not allow states parties to claim that they do not have any resources for the implementation of social and economic goods for the fulfilment of children's rights" (African Committee of Experts on the Rights and Welfare of the Child 2018, p. 7). Furthermore, the African Committee explains it will "scrutinise diligently claims that non-fulfilment of rights is linked to non-availability of resources" and expects that States parties show "rapid forward progress in extending the reach and impact" of measures to realise children's rights (African Committee of Experts on the Rights and Welfare of the Child 2018, pp. 8-9).

The CRC Committee urges States "to adopt comprehensive, strategic and time-bound coordinating frameworks for child caregiving and protection" (United Nations Committee on the Rights of the Child 
2011, para. 73). Similarly, the African Committee calls for "a national policy for children that provides a common, unifying, comprehensive and rights-based framework of action for all role-players", which is costed, has measurable targets and budget allocations (African Committee of Experts on the Rights and Welfare of the Child 2018, p. 35). It is within such frameworks that responsibilities of NGOs in contact with children can be embedded.

In view of "different starting points", and on the understanding that budgets on national and decentralised levels should be the primary source of funds for child protection, the CRC Committee has drawn the attention of States parties to the avenues of international cooperation and assistance outlined in Articles 4 and 45 of the CRC (United Nations Committee on the Rights of the Child 2011, para. 74). The CRC Committee states that implementation of the CRC is "a cooperative exercise for the States of the world" and that the CRC "should form the framework for international development assistance related directly or indirectly to children and that programmes of donor States should be rights-based" (United Nations Committee on the Rights of the Child 2003, paras. 60, 61). The African Committee also encourages State Parties to ensure children's rights are "deliberately reflected and adequately catered for in all donor aid agreements, including with global finance institutions" (African Committee of Experts on the Rights and Welfare of the Child 2018, p. 41). In General Comment No. 13 (2011) on the right of the child to freedom from all forms of violence, the CRC Committee reiterates that child rights-based protection programmes should be one of the main components in assisting sustainable development in countries receiving international assistance (United Nations Committee on the Rights of the Child 2011, para. 74). This is reflected in part in the DAC Recommendation, in which signatories have expressly acknowledged the importance of strengthening child protection services. While forming part of recommendations by UNHCR and Save the Children (United Nations High Commissioner for Refugees \& Save the Children UK 2002) and Csáky (Csáky 2008), this important element has not received significant attention in recent safeguarding discussions.

\subsection{Applicability to Non-State Actors}

At the very least, there are 'indirect' children's rights obligations for non-State actors to comply with children's treaty-based rights. In General Comment No. 5 (2003) on General Measures of Implementation, the CRC Committee emphasises that the legal obligation of State parties "to respect and ensure the rights of children as stipulated in the Convention" includes the "obligation to ensure that non-State service providers operate in accordance with its provisions, thus creating indirect obligations on such actors" (United Nations Committee on the Rights of the Child 2003, para. 6).

The CRC Committee further elaborates that child rights responsibilities extend in practice "beyond the State and State-controlled services and institutions to include children, parents and wider families, other adults, and non-State services and organisations" (United Nations Committee on the Rights of the Child 2003, para. 56). The CRC Committee has taken a broad view of NGOs constituting, for example, human rights NGOs, child- and youth-led organisations and youth groups, parent and family groups, faith groups, academic institutions and professional associations (United Nations Committee on the Rights of the Child 2003, para. 58). This broad view is particularly relevant in the African context where most services to children are delivered by civil society organisations (CSOs). These can include NGOs, faith-based organisations, volunteer networks, social enterprises, or philanthropic projects connected to for-profit companies (Parker 2018a, p. 2). Organisations that encounter children are not only those that provide social services such as education, health, nutrition, recreation, alternative care, and protection but also other services, including water and sanitation, infrastructure, as well as humanitarian relief.

The CRC Committee has also expressed its agreement with the Committee on Economic, Social and Cultural Rights in its General Comment No. 14 (2000) of the right to the highest attainable standard of health. Paragraph 42 of the General Comment reiterates that as parties to the Covenant, States are "ultimately accountable for compliance with it" but responsibilities for realisation of the right to health fall to all members of society, including health professionals, families, local communities, 
intergovernmental and NGOs, CSOs, and the private business sector. States parties are therefore called to "provide an environment which facilitates the discharge of these responsibilities" (United Nations Committee on the Rights of the Child 2003, para. 56).

\subsection{Best Interests of the Child}

The best interests' principle is fundamental and especially relevant for child safeguarding in the aid sector. Article 3(1) of the CRC provides that the best interests of the child shall be a primary consideration in "all actions concerning children, whether undertaken by public or private social welfare institutions, courts of law, administrative authorities or legislative bodies." Importantly, the CRC Committee elaborates that "public or private social welfare institutions" should not be narrowly construed or limited to strictly social institutions but would apply to "all institutions whose work and decisions impact on children and the realisation of their rights" (United Nations Committee on the Rights of the Child 2013, para. 26).

The CRC Committee notes these would be bodies "not only those related to economic, social and cultural rights (e.g., care, health, environment, education, business, leisure and play, etc.), but also institutions dealing with civil rights and freedoms (e.g., birth registration, protection against violence in all settings, etc.)" (United Nations Committee on the Rights of the Child 2013, para. 26). Private bodies include "either for-profit or non-profit-which play a role in the provision of services that are critical to children's enjoyment of their rights, and which act on behalf of or alongside Government services as an alternative" (United Nations Committee on the Rights of the Child 2013, para. 26). This extension of this obligation to private social welfare organisations is quite unusual in an international treaty (Eekelaar and John 2019, p. 80).

The CRC Committee explains that Article 3 has implications for all implementation measures taken by governments, individual decisions made by judicial or administrative authorities or public entities through their agents, decisions made by civil society entities and the private sector, including profit and non-profit organisations, which provide services concerning or impacting on children, and guidelines for actions undertaken by persons working with and for children, including parents and caregivers (United Nations Committee on the Rights of the Child 2013, pt. II). The best interests' principle should therefore be the primary consideration in all actions concerning children undertaken by humanitarian and development organisations. Guidance from the African Committee reinforces the broad application of the best interests' principle. In its General Comment No. 5 on State Party Obligations under the African Charter on the Rights and Welfare of the Child (Article 1) and Systems Strengthening for Child Protection, the African Committee states that Article 4(1) of the ACRWC provides that the best interests of the child shall be the primary consideration and this applies to both private and public institutions (African Committee of Experts on the Rights and Welfare of the Child 2018, p. 11). The African Committee explains it is therefore "the responsibility of the State Party to ensure to the maximum extent possible that private actors, including ... various non-state actors engaged with children's rights and services, are aware of and apply the best interests of the child in all of their endeavours" (African Committee of Experts on the Rights and Welfare of the Child 2018, p. 11).

Furthermore, Article 3(3) of the CRC provides: "State Parties shall ensure that the institutions, services and facilities responsible for the care or protection of children shall conform with the standards established by competent authorities, particularly in the areas of safety, health, in the number and suitability of their staff, as well as competent supervision." While some doubt was expressed as to the appropriateness of this provision, the legislative history suggests the rationale was to apply the best interests' principle to the very specific area of institutional care and service provision (Office of the United Nations \& High Commissioner for Human Rights 2007, pp. 347-48). The application in alternative care settings is also explicit in the commentary of the African Committee (African Committee of Experts on the Rights and Welfare of the Child 2018, p. 12).

There has been little exploration of this article, yet it is highly relevant to safeguarding discourse. In Africa, most institutional care is provided by NGOs and faith-based organisations, many of which 
are funded by faith communities or individual donors from the Global North, and which often fail to register or comply with relevant government regulations (see for example Munthali 2019, p. 13). In its General Comment No. 5 (2003) on General Measures of Implementation, the CRC Committee emphasises that "enabling the private sector to provide services, run institutions and so on does not in any way lessen the State's obligation to ensure for all children within its jurisdiction the full recognition and realisation of all rights in the Convention." In relation to Article 3 (3), the CRC Committee explains that rigorous inspection is required to ensure compliance and proposes "a permanent monitoring mechanism or process aimed at ensuring that all State and non-State service providers respect the Convention" (United Nations Committee on the Rights of the Child 2003, para. 27).

\subsection{Intra-Organisational Processes and Codes of Conduct}

In General Comment No. 13 (2011) on the right of the child to freedom from all forms of violence, the CRC Committee explains that administrative measures under Article 19 of the CRC "should reflect governmental obligations to establish policies, programmes, monitoring and oversight systems required to protect the child from all forms of violence" ((United Nations Committee on the Rights of the Child 2011, para. 42(b))). These include the development and implementation "through participatory processes which encourage ownership and sustainability" of intra- and inter-agency child protection policies and professional ethics codes, protocols, memoranda of understanding and standards of care for all childcare services and settings, for all levels of government and civil society institutions. Settings include daycare centres, schools, hospitals, sport clubs and residential institutions ((United Nations Committee on the Rights of the Child 2011, para. 42(b))). The implementation by government and civil society of rights-based child protection policies and procedures and professional ethics codes and standards of care are also mentioned by the CRC Committee in relation to 'prevention measures' (United Nations Committee on the Rights of the Child 2011, para. 47).

The emphasis on ownership and sustainability is important, otherwise there is a risk that the endeavour becomes a 'tick-box' exercise. In other words, if the codes and policies are to impact positively on children's protection, the process will require more than preparing paperwork that is filed and forgotten. There is a need for meaningful consultation among stakeholders, including children and young people themselves, and consideration of how international and regional standards can be implemented in a local context, in the best interests of the child. The values and behaviours elaborated within codes and policies must be owned and championed by organisational leaders and staff, and safeguarding policies and practice continually monitored, assessed and adapted. Pressure to produce a checklist of policies and procedures driven by a compliance imperative is unlikely to lead to change that improves children's protection.

The African Committee has echoed the importance of policies and personnel of NGOs in its recent General Comment No. 5 on State Party Obligations under the African Charter on the Rights and Welfare of the Child (Article 1) and Systems Strengthening for Child Protection. The African Committee requires civil society organisations and international organisations working with children to adopt child safeguarding policies. Furthermore, the Committee suggests persons who have abused children should not be able to work with children, even as volunteers. Importantly, especially for the African context where NGO-government relationships in some countries are "characterised by a large amount of distrust, cooptation, and outright repression"(Gugerty 2010, p. 1090), the African Committee urges "State Parties to review the legislation governing the registration and operation of CSOs to ensure that it does not provide any impediment to their optimal functioning"(African Committee of Experts on the Rights and Welfare of the Child 2018). While there are different legal frameworks and self-regulatory mechanisms for NGOs across the continent (Gugerty 2010), child protection and safeguarding measures are not yet incorporated. Both the CRC and African Committees could raise questions on such standards in its list of issues for State party reports as part of their external oversight role. 


\section{Key Dilemmas and Challenges for Child Safeguarding}

This final section sets out key areas for further consideration and critical debate by practitioners and policymakers in the effort to safeguard children from harm in the context of humanitarian and development activity. Recent developments and commitments are significant and promising. However, to harness the current momentum and ensure initiatives in the Global North positively impact children's safety in the least developed countries, there is arguably scope for a more nuanced and contextualised approach, guided by children's treaty-based rights and the best interests' principle.

Current sectoral efforts appear to largely focus on international NGOs with headquarters in the Global North and the risk of a 'Western' offender harming children in the world's poorest countries. This does not reflect the variety of organisations inhabiting the aid space and in contact with children. The focus on 'Western' staff is arguably disproportionate given that local staff make up the majority of the workforce in the developing world and both local and 'foreign' staff (of all levels) have been implicated in cases of child abuse (Csáky 2008, p. 9). This reality suggests that high-profile initiatives such as the global criminal records register may have a limited impact on the protection of children in the developing world. Firstly, a global criminal records register assumes that the person has already come to the attention of police and justice systems. It is well evidenced that "much abusive behaviour has historically gone unreported" and the majority of "perpetrators detected do not have prior convictions for any form of child maltreatment" (Tilbury 2014, p. 92). Secondly, the register assumes that there are functioning information management systems in the countries in which personnel have resided in order to be able to feed into the global database. This is not the case in most developing countries in Africa.

By way of example, even in one of the most developed countries on the continent, South Africa, implementing a scheme to identify persons unsuitable to work with children has proved largely unsuccessful. South Africa's Children's Act (Act No. 38 of 2005) mandates the Department of Social Development to keep and maintain a Child Protection Register (section 111), which consists of two parts. Part A records all reports of abuse or deliberate neglect of a child and Part B lists persons declared unsuitable to work with children. The Act requires all organisations to assess and verify the suitability of employees and potential employees who will "work with or have access to children" (section 126). As of March 2019, the register has 509 names of persons declared unsuitable to work with children and the department has only received 140,029 suitability check enquiries from employers and individuals. With over 10 million people in South Africa employed in the formal non-agricultural sector (Department of Statistics, South Africa 2019), the small number of suitability checks makes it clear that the register is not functioning optimally. Among other challenges, the register is constrained in that it does not align with the National Register for Sexual Offenders, resulting in critical omissions in the list of crimes that warrant inclusion on the register, such as attempted rape (KPMG 2016, pp. 42-43).

Even high-income countries with functional and routine criminal records checks for determining suitability of working with children are increasingly cognisant of their limitations. In Australia, for example, some commentators suggest the scope of screening regimes risk being "too big and too expensive to be sensible" (Tilbury 2014, p. 92). At worst, an overreliance on such mechanisms can be detrimental to children's safety. The Royal Commission into Institutional Responses to Child Sexual Abuse in Australia—one of the most probing government inquiries to have taken place-found that Australia's Working with Children Checks can provide a "false sense of comfort to parents and communities and may cause organisations to become complacent" due to the mistaken belief that people who have undergone these checks do not pose any risks to children (Australia \& Royal Commission into Institutional Responses to Child Sexual Abuse 2015, p. 3).

Screening is only one in a range of strategies needed to make organisations child safe. Rather than a sole focus on trying to identify individuals and prevent them entering organisations, lessons from other jurisdictions emphasise to the need "to modify environments, thereby reducing the likelihood that anyone could engage in abusive behaviour" (Higgins et al. 2016, pp. 54-55). There should also be attention on the structures and opportunities within the sector that enable abuse to occur. Lessons 
may be drawn from the large body of literature about the role of institutions (both government and non-government) with responsibility for children in preventing and responding to child sexual abuse. The UK Independent Inquiry into Child Sexual Abuse, for example, commissioned a Rapid Evidence Assessment and identified structural and organisational factors shown to facilitate child sexual abuse (Radford et al. 2016). These included privacy and the offender being alone with the child, persons in positions of trust having little supervision or monitoring, lack of safeguarding policies, failure to report or to sanction offenders, a culture where abuse is normalised, hierarchical organisations where it is difficult for junior staff to complain, lack of an adequate complaints system, and a lack of safe space for children who are victimised to tell anyone about the abuse, and to have complaints acted on appropriately (Radford et al. 2016, p. 17). This highlights the limitations of 'tick-box' exercises focused on paperwork and calls for a localised and thorough assessment of how NGOs in the developing world interact with children and what risks these interactions present.

On a larger scale, this also requires the sector to grapple with the inequitable power relations that characterise their interactions with communities and children. In the 2008 Humanitarian Accountability Partnership report of consultations with aid beneficiaries on their perceptions of efforts to prevent and respond to sexual exploitation and abuse, Lattu (Lattu 2008, p. 52) concluded that the single most important reason for the "humanitarian accountability deficit" is the uneven relationship between agencies delivering aid and users of humanitarian assistance which puts the users "at a structural disadvantage in their relationship with humanitarian aid providers." This inequitable relationship is echoed in the voices of children, captured in empirical evidence on the subject. For example, an adolescent girl in Liberia is quoted as saying: "These NGO workers they are clever they use the ration as bait to get you to have sex with them" (United Nations High Commissioner for Refugees \& Save the Children UK 2002, p. 44). Similarly, the following quote from an adolescent girl in Cote d'Ivoire, "He's using the girl but without him she won't be able to eat", and an adolescent boy in South Sudan, "People don't report it because they are worried that the agency will stop working here, and we need them" (Csáky 2008, p. 7). This observation is not new, nor limited to children, but it is one that has arguably not yet been adequately addressed. It calls for transformative change in the sector. There are indications of some organisations starting to contend with these entrenched power dynamics.

In addition to inequitable power relations, safeguarding efforts need to pay greater attention to longstanding attitudes and beliefs on child abuse and appropriate responses to it. These social and cultural norms form part of the "very different starting points" in the implementation of children's rights as highlighted by the CRC Committee (United Nations Committee on the Rights of the Child 2011, para. 70). Social and cultural norms relating to children and child abuse may be either protective of children or enhance their vulnerability. These norms need to be considered in safeguarding efforts as they are both risk factors and barriers to help seeking. While not representative across the continent or within countries, the following harmful norms have been identified in the literature: gender norms and gender socialisation including about social roles or expectations that differentiate males and females and place children at increased risk of sexual abuse (Gwirayi 2010; Plummer and Njuguna 2009); patriarchy including male dominance or perceived superiority that can perpetuate abuse, male violence and traditional notions of masculinity and normalisation of inter-personal violence (Gwirayi 2010; Lalor 2004; Petersen et al. 2005; Plummer and Njuguna 2009); a 'culture of silence' relating to sexual matters and discouraging speaking up about sexual violence (Plummer and Njuguna 2009); and sexual norms including sexual initiation rites or harmful practices including female genital mutilation and child marriage (Plummer and Njuguna 2009), and the myth of sexual intercourse with a young child to 'cure' sexually transmitted diseases including HIV/AIDs (Lalor 2004). Many of these norms intersect with norms that enable violence against women but there are also distinct norms relating to children including their low status and socialisation for obedience and acquiescence (Lalor 2004; Plummer and Njuguna 2009). By way of example, the following quote from a South Sudanese girl is illustrative of various attitudes and practices at play that contribute to individual and community responses to abuse: "The father would try to persuade the man to take the girl as a bride and to pay cattle for her. 
He would not ask the girl whether she wants this. So really the girl gets no advantage from telling anyone about the abuse" (Csáky 2008, p. 17). Norms on masculinity also contribute to low disclosure rates by boys that experience sexual abuse (Guedes et al. 2016, p. 6). Importantly, those beliefs and norms found on the community level also manifest amongst the local staff of aid organisations as well as the staff and volunteers of their implementing partners (Sloth-Nielsen 2014, p. 957). Additionally, they will be found amongst duty bearers or service providers that will be called upon to respond when allegations of child abuse emerge and are reported.

Closely linked to this point, in most of Africa's least developed countries, the institutional dimensions to address child abuse (such as infrastructure in law enforcement, judiciary, health and social welfare) are constrained. Victim and witness protections are weak and reporting to formal services may put children and communities at further risk. This raises potential ethical dilemmas for reporting abuse. Walker-Simpson argues that "the very act of reporting abuse may actually expose the child to additional risk" in contravention to the 'do no harm' principle (Walker-Simpson 2017, p. 258). Informal community practices are often the prevailing system employed for dealing with child abuse. While these may not always seem to provide adequate protection when "judged through a Western lens", they are "often considered the least stigmatising, most accessible, and most helpful of interventions by communities" (Krueger et al. 2015, p. 22). This highlights the criticality of meaningful consultation and addressing the attitudes and expectations of local people, otherwise "no matter how strong an NGO's internal safeguards, if children and their caregivers are unwilling or unable to report abuse, protection procedures will remain 'fatally flawed'" (Walker-Simpson 2017, p. 259).

The push to establish complaints mechanisms for specific projects or organisations can also be problematic, especially in the absence of a functioning system at local or national level. Parallel systems risk creating perverse situations, where there is a system in place to refer, investigate, report, and act upon cases of violence only if it is perpetrated by an aid worker. Violence against children in the context of aid cannot be detached from child protection generally, just as sexual exploitation and abuse by aid workers cannot be detached from gender-based violence generally (Stern 2018). There is a need to "move away from programming silos focussed on perpetrators and their acts", and instead focus "on victims and their harm" (Stern 2018). There is some parallel to efforts to disrupt child sexual abuse and exploitation in the context of tourism, especially in South East Asia, where international advocacy and programmes focused more on the foreign sex offender and less on the underlying and interlinked factors contributing to children's vulnerability (Kaviani Johnson 2014). Similarly, research shows that those children vulnerable to abuse by aid workers are "already vulnerable children" including orphans, children with disabilities, children separated from their parents, children from especially poor families, children who are discriminated and marginalised, children displaced from their home communities, migrant, refugee and asylum-seeking children, and children from families who depend on humanitarian assistance (Csáky 2008, p. 7). The African Committee calls for a systems-strengthening approach to child protection and explains that an issues-based approach has, in the past, "resulted in a fragmented child protection response, marked by numerous inefficiencies and pockets of unmet need" (African Committee of Experts on the Rights and Welfare of the Child 2018, p. 33). It follows that investment in child protection systems strengthening is strongly interlinked with the responsibility of delivering aid in a way that does no harm and would sustain efforts to ensure protection of children in the developing world.

Finally, there are new challenges for children's rights, which arise from development and humanitarian activity in the digital era. The Committee on the Rights of the Child is currently drafting a General Comment on children's rights in relation to the digital environment. One group of rights to be realised in a digital world is the protection of privacy, identity and data processing. This is highly relevant for aid organisations in the developing world. The aid sector uses mobile telecommunications, messaging apps and social media to coordinate their work, communicate with staff and volunteers, and engage with the people they serve ((International Committee of the Red Cross ICRC, p. 11)). Many African countries are also seen as a "testing ground" for technologies produced elsewhere and, 
as a consequence, the personal data of people on the continent, including children, are increasingly stored in hundreds of databases (Privacy International 2020). This is especially relevant with current digital health surveillance in the response to COVID-19. The way in which data, including children's data, is collected and is used is changing quickly and the ongoing accumulation of data about children throughout their lifetime can create a variety of unforeseen risks and challenges (Viola de Azevedo Cunha 2017). Some children, for example, refugee children, may be particularly vulnerable to invasions of privacy in the form of data surveillance as well as dangers resulting from data-leaks or misuses (Peace Research Institute Oslo 2018). This is an area for further examination and focus for the sector.

\section{Conclusions}

The increased attention and strong consensus and commitment to address sexual exploitation and abuse in the aid sector is commendable. The suite of standards may coordinate and socialise NGOs in advancing child safeguarding and reducing organisational risk, especially for those NGOs with headquarters - or funded by donors-in the Global North. This is an important endeavor given the fact that, in many of the world's least developed countries, non-State actors deliver the majority of services to children and thus have an important role to play in contributing towards their protection. Furthermore, as discussed, non-State actors have-at the very least-'indirect' obligations to comply with children's treaty-based rights. Going forward, it is suggested that the safeguarding discourse applies a child rights-based approach and considers the various intersections between humanitarian and development activity and children's treaty-based rights. This should encompass all risks and harms, including those emerging in the digital age. Furthermore, given the strong links and dependency between intra-organisational efforts and national systems, there is a need to go beyond intra-organisational policies and self-regulation. NGOs and governments must be jointly and severally responsible for child safeguarding. In the case of national governments, progressive improvement of child protection standards and oversight of non-State actors working with children is required. To do this, national and international investment is needed for strengthening child protection systems on national and local levels in the developing world. To be sustainable and contribute to meaningful change for children, efforts cannot be driven by the latest scandal, but must be motivated by a genuine commitment to children's treaty-based rights. With less than ten years to achieve Agenda 2030 and at a time where the world is battling COVID-19, which rapidly risks becoming a child rights crisis (UNICEF 2020; United Nations Committee on the Rights of the Child 2020), this is more important than ever before.

Author Contributions: A.K.J. drafted the article with conceptual inputs and supervision from J.S.-N. Editing was shared. All authors have read and agreed to the published version of the manuscript.

Funding: This research received no external funding.

Acknowledgments: The authors thank two anonymous reviewers for critically reading the manuscript and providing helpful comments.

Conflicts of Interest: The authors declare no conflict of interest.

\section{References}

African Committee of Experts on the Rights and Welfare of the Child. 2018. General Comment No 5 on "State Party Obligations under the African Charter on the Rights and Welfare of the Child (Article 1) and Systems Strengthening for Child Protection.". Available online: https://www.acerwc.africa/wp-content/uploads/ 2019/09/ACERWC\%20General\%20Comment\%20on\%20General\%20Measures\%20of\%20Implementation\% 20African\%20Children\T1 \textquoterights\%20Charter.pdf (accessed on 16 February 2020).

AusAID. 2013. Child Protection Policy-January 2013-World. ReliefWeb. February 8. Available online: https://reliefweb.int/report/world/child-protection-policy-january-2013 (accessed on 3 March 2020). 
Australia \& Royal Commission into Institutional Responses to Child Sexual Abuse. 2015. Working with Children Checks Report. Royal Commission into Institutional Responses to Child Sexual Abuse. Available online: http://www.childabuseroyalcommission.gov.au/policy-and-research/working-with-children-checks/ working-with-children-checks-report (accessed on 3 March 2020).

BBC. 2018. How the Oxfam Scandal Unfolded. BBC News. February 21. Available online: https://www.bbc.com/ news/uk-43112200 (accessed on 28 March 2020).

Bond. 2019. Our Commitment to Change in Safeguarding. Available online: https://assets.publishing.service.gov. uk/government/uploads/system/uploads/attachment_data/file/851112/bond-safeguarding-commitmentsnov2019.pdf (accessed on 5 March 2020).

Charity Commission for England and Wales. 2019. Inquiry Report, Summary Findings and Conclusions. Available online: https://assets.publishing.service.gov.uk/government/uploads/system/uploads/attachment_data/file/ 807943/Inquiry_Report_summary_findings_and_conclusions_Oxfam.pdf (accessed on 5 March 2020).

Commitments Made by Donors to Tackle Sexual Exploitation and Abuse and Sexual Harassment in the International Aid Sector. 2018. Available online: https://assets.publishing.service.gov.uk/government/uploads/system/ uploads/attachment_data/file/749632/donor-commitments1.pdf (accessed on 15 March 2020).

Core Humanitarian Standard (CHS) Alliance, The Sphere Project, and Groupe URD. 2015. Core Humanitarian Standard Guidance Notes and Indicators. Available online: https:/corehumanitarianstandard.org/files/files/ CHS_guidance_notes.pdf (accessed on 15 February 2020).

Csáky, Corrina. 2008. No One to Turn to: The Under-Reporting of Child Sexual Exploitation and Abuse by Aid Workers and Peacekeepers. London: Save the Children.

Department of Statistics, South Africa. 2019. December 12. 28000 Jobs Lost in SA Formal Sector Third Quarter of 2019|Statistics South Africa. Statistics South Africa. Available online: http://www.statssa.gov.za/?p=12842 (accessed on 30 March 2020).

Donovan, Paula. 2018. Open Letter to the Rt Hon Penny Mordaunt, MP. October 17. Available online: https:/static1.squarespace.com/static/514a0127e4b04d7440e8045d/t/5bc777b99140b756d661e476/ 1539798969879/2018-10-17\%2C+Letter+to+Minister+Mordaunt.pdf (accessed on 14 March 2020).

Edwards, Sophie. 2019. DFID Gives up on Idea for an International Safeguarding Ombudsman; Washington: Devex, October 23. Available online: https://www.devex.com/news/dfid-gives-up-on-idea-for-an-internationalsafeguarding-ombudsman-95886 (accessed on 18 January 2020).

Eekelaar, John, and Tobin John. 2019. Article 3. The Best Interests of the Child. In The UN Convention on the Rights of the Child: A Commentary. Oxford: Oxford University Press, pp. 73-107.

Gillespie, Elizabeth, Mirabella Roseanne, and Eikenberry Angela. 2019. \#Metoo/\#Aidtoo and Creating an Intersectional Feminist NPO/NGO Sector. Nonprofit Policy Forum 10. [CrossRef]

Guedes, Alessandra, Sarah Bott, Claudia Garcia-Moreno, and Manuela Colombini. 2016. Bridging the gaps: A global review of intersections of violence against women and violence against children. Global Health Action 9: 31516. [CrossRef] [PubMed]

Gugerty, Mary Kay. 2010. The Emergence of Nonprofit Self-Regulation in Africa. Nonprofit and Voluntary Sector Quarterly 39: 1087-112. [CrossRef]

Gwirayi, Pesanayi. 2010. The Role of Macro-Systemic Contexts in Understanding the Aetiology and Epidemiology of Child Sexual Abuse in Southern Africa. Journal of Sustainable Development in Africa 12: 253-68.

Higgins, Daryl J., Keith Kaufman, and Marcus Erooga. 2016. How can child welfare and youth-serving organisations keep children safe? Developing Practice 44: 48.

Hilhorst, Dorothea, Naik Asmita, and Cunningham Andrew. 2018. International Ombuds for Humanitarian and Development Aid Scoping Study. The Hague: Netherlands Ministry of Foreign Affairs/Erasmus University-International Institute of Social Studies.

HM Government. 2018. Working Together to Safeguard Children: Statutory Framework: Legislation Relevant to Safeguarding and Promoting the Welfare of Children. p. 13. Available online: https://assets.publishing.service.gov.uk/government/uploads/system/uploads/attachment_data/file/ 722307/Working_Together_to_Safeguard_Children_Statutory_framework.pdf (accessed on 12 February 2020).

House of Commons, International Development Committee. 2018. Sexual Exploitation and Abuse in the Aid Sector. Eighth Report of Session 2017-19. p. 120. Available online: https://publications.parliament.uk/pa/ cm201719/cmselect/cmintdev/840/840.pdf (accessed on 15 February 2020). 
Humanitarian Advisory Group. 2018. From an Ombudsman to a Humanitarian Passport: How Should We Be Addressing Abuse in the International Aid Sector? Independent Think Piece. Available online: https://humanitarianadvisorygroup.org/wp-content/uploads/2018/05/HAG-SafeguardingThinkpiece-May-2018.pdf (accessed on 7 April 2020).

Inter-Agency Standing Committee. n.d. IASC Products on Protection from Sexual Exploitation and Abuse. Inter-Agency Standing Committee. Available online: https://interagencystandingcommittee.org/resources/ iasc-products?f\%5B0\%5D=product_category $\% 3$ AProtection $\% 20$ from $\% 20$ Sexual $\% 20$ Exploitation $\% 20$ and $\%$ 20Abuse (accessed on 10 April 2020).

International Committee of the Red Cross (ICRC) \& Privacy International. 2018. The Humanitarian Metadata Problem: "Doing No Harm in the Digital Era.". Available online: https://privacyinternational.org/sites/ default/files/2018-12/The\%20Humanitarian\%20Metadata\%20Problem\%20-\%20Doing\%20No\%20Harm\% 20in\%20the\%20Digital\%20Era.pdf (accessed on 14 February 2020).

Kaviani Johnson, Afrooz. 2014. Protecting Children's Rights in Asian Tourism. The International Journal of Children's Rights 22: 581-617. [CrossRef]

Keeping Children Safe. 2014. Child Safeguarding Standards and How to Implement Them. Available online: https://resourcecentre.savethechildren.net/library/child-safeguarding-standards-and-howimplement-them (accessed on 16 February 2020).

Keeping Children Safe. n.d. Strategic Plan 2019-2022. Available online: https:/www.keepingchildrensafe.global/ wp/wp-content/uploads/2019/12/Strategy-Report-191018-singles-2.pdf (accessed on 7 April 2020).

KPMG. 2016. Report on Diagnostic Review of the State Response to Violence against Women and Children; Pretoria: Department of Planning, Monitoring and Evaluation, Department of Social Development (South Africa). Available online: https:/genderjustice.org.za/wp-content/uploads/2017/12/Report-Diagnostic-Review-StateResponse-VAWC.pdf (accessed on 8 February 2020).

Krueger, Alexander, Emma de Vise-Lewis, Guy Thompstone, and Vimala Crispin. 2015. Child protection in development: Evidence-based reflections \& questions for practitioners. Child Abuse E Neglect 50: 15-25. [CrossRef]

Lalor, Kevin. 2004. Child sexual abuse in sub-Saharan Africa: A literature review. Child Abuse E Neglect 28: 439-60. [CrossRef]

Lattu, Kirsti. 2008. To Complain or Not to Complain: Still the Question; Geneva: Humanitarian Accountability Partnership, p. 62. Available online: http:/www.pseataskforce.org/uploads/tools/ tocomplainornottocomplainstillthequestion_hapinternational_english.pdf (accessed on 29 March 2020).

Munthali, Alister C. 2019. Reintegrating Children from Institutional Care: A Feasibility Study on a Model for Malawi; Lilongwe: Government of Malawi, Ministry of Gender, Children, Disability and Social Welfare, UNICEF. Available online: https://www.unicef.org/malawi/media/1291/file/UNICEF\%20Reintegration\%20Children\% 20Feasibility\%20Study.pdf (accessed on 6 April 2020).

OECD Development Assistance Committee. 2019. DAC Recommendation on Ending Sexual Exploitation, Abuse, and Harassment in Development Co-Operation and Humanitarian Assistance: Key Pillars of Prevention and Response. Available online: https://legalinstruments.oecd.org/en/instruments/OECD-LEGAL-5020 (accessed on 18 January 2020).

Office of the United Nations \& High Commissioner for Human Rights. 2007. Legislative History of the Convention on the Rights of the Child, Volume 1 (HR/PUB/07/1); New York and Geneva: United Nations. Available online: https://resourcecentre.savethechildren.net/node/8015/pdf/legislativehistorycrc1en_1.pdf (accessed on 15 March 2020).

Parker, Ben. 2018a. \#MeToo Sex Scandals Spur Interest in Standards for the Aid Sector; Geneva: The New Humanitarian, May 2. Available online: https://www.thenewhumanitarian.org/analysis/2018/05/02/metoo-sex-scandalsspur-interest-standards-aid-sector (accessed on 14 March 2020).

Parker, Ben. 2018b. Schemes to Stop Sex Abuse in the Aid Sector off to a Shaky Start. Geneva: The New Humanitarian, October 18, Available online: https://www.thenewhumanitarian.org/news-feature/2018/10/18/safeguardingaid-sector-sex-abuse-shaky-start (accessed on 14 March 2020).

Peace Research Institute Oslo. 2018. Smart Phones for Refugees: Tools for Survival, or Surveillance? Available online: https://www.prio.org/utility/DownloadFile.ashx?id=1597\&type=publicationfile (accessed on 3 April 2020). 
Petersen, Inge, Arvin Bhana, and Mary McKay. 2005. Sexual violence and youth in South Africa: The need for community-based prevention interventions. Child Abuse \& Neglect 29: 1233-48. [CrossRef]

Plummer, Carol A., and Wambui Njuguna. 2009. Cultural protective and risk factors: Professional perspectives about child sexual abuse in Kenya. Child Abuse \& Neglect 33: 524-32. [CrossRef]

Privacy International. 2020. 2020 Is a Crucial Year to Fight for Data Protection in Africa. Privacy International. March 3. Available online: https://privacyinternational.org/long-read/3390/2020-crucial-year-fight-dataprotection-africa (accessed on 4 April 2020).

Radford, Lorraine, Helen Richardson Foster, Christine Anne Barter, and Nicky Stanley. 2016. Rapid Evidence Assessment: What Can Be Learnt from Other Jurisdictions about Preventing and Responding to Child Sexual Abuse, Report for the Independent Inquiry into Child Sexual Abuse. Lancashire: Connect Centre for International Research on Interpersonal Violence Faculty of Social Work, Care \& Community, University of Central Lancashire.

Sandvik, Kristin Bergtora. 2019. 'Safeguarding' as humanitarian buzzword: An initial scoping. Journal of International Humanitarian Action 4: 3. [CrossRef]

Sloth-Nielsen, Julia. 2014. Regional Frameworks for Safeguarding Children: The Role of the African Committee of Experts on the Rights and Welfare of the Child. Social Sciences 3: 948-61. [CrossRef]

Sloth-Nielsen, Julia. 2018. Monitoring and Implementation of Children's Rights. In International Human Rights of Children. Edited by Liefaard Ton and Kilkelly Ursula. Singapore: Springer, pp. 1-35. [CrossRef]

Steering Committee for Humanitarian Response, Misconduct Disclosure Scheme. n.d. Steering Committee for Humanitarian Response. Available online: https://www.schr.info/the-misconduct-disclosure-scheme (accessed on 5 April 2020).

Stern, Orly. 2018. First Person: Two Nearly Identical Cases of Sex Abuse; Two Very Different Responses; Geneva: The New Humanitarian, June 27. Available online: http://www.thenewhumanitarian.org/opinion/2018/06/27/firstperson-two-nearly-identical-cases-sex-abuse-two-very-different-responses (accessed on 29 March 2020).

Tilbury, C. 2014. Working with children checks -time to step back? Australian Journal of Social Issues 49: 87-100. [CrossRef]

Tobin, John, and Florence Seow. 2019. Article 34. Protection from Sexual Exploitation and Sexual Abuse. In The UN Convention on the Rights of the Child: A Commentary. Oxford: Oxford University Press, pp. 1310-54.

UK Department for International Development. 2018a. International Development Secretary Penny Mordaunt Gives Key-Note Speech at the Safeguarding Summit 2018; October 18, GOV.UK. Available online: https://www.gov.uk/government/speeches/international-development-secretary-penny-mordauntgives-key-note-speech-at-the-safeguarding-summit-2018 (accessed on 29 March 2020).

UK Department for International Development. 2018b. Progress Report on Delivering the Donor Commitments from the October 2018 London Safeguarding Summit; p. 33 . Available online: https://assets.publishing.service.gov.uk/government/uploads/system/uploads/attachment_data/file/ 840067/Progress-report-on-delivering-donor-commitments.pdf (accessed on 5 March 2020).

UK Department for International Development. 2019. Progress Report-One Year on from the October 2018 London Safeguarding Summit; London: UK Department for International Development. Available online: https://assets.publishing.service.gov.uk/government/uploads/system/uploads/attachment_data/file/ 840063/Cross-sector-Safeguarding-Progress-Report-Oct_19.pdf (accessed on 18 January 2020).

UK Parliament. 2018. Sexual Exploitation and Abuse in the Aid Sector Inquiry Launched-News from Parliament; London: UK Parliament, March 5. Available online: https:/www.parliament.uk/business/committees/ committees-a-z/commons-select/international-development-committee/news-parliament-2017/sexualexploitation-launch-17-19-/ (accessed on 15 February 2020).

UNICEF. 2020. Don't Let Children Be the Hidden Victims of COVID-19 Pandemic; New York: UNICEF, April 9. Available online: https://www.unicef.org/press-releases/dont-let-children-be-hidden-victims-covid-19-pandemic (accessed on 10 April 2020).

United Nations Committee on the Rights of the Child. 2003. General Comment No. 5 (2003), General Measures of Implementation of the Convention on the Rights of the Child (arts. 4, 42 and 44, para. 6). 34th Session, adopted 27 November 2003, CRC/GC/2003/5. Available online: https://tbinternet.ohchr.org/ _layouts/15/treatybodyexternal/Download.aspx?symbolno=CRC\%2fGC\%2f2003\%2f5\&Lang=en (accessed on 22 January 2020). 
United Nations Committee on the Rights of the Child. 2011. General comment No. 13 (2011), The Right of the Child to Freedom from All Forms of Violence. Adopted 18 April 2011, CRC/C/GC/13. Available online: https://tbinternet.ohchr.org/_layouts/15/treatybodyexternal/Download.aspx?symbolno=CRC\%2fC\% 2fGC\%2f13\&Lang=en (accessed on 22 January 2020).

United Nations Committee on the Rights of the Child. 2013. General Comment No. 14 (2013) on the Right of the Child to Have His or Her Best Interests Taken as a Primary Consideration (art 3, para 1). $62^{\text {nd }}$ Session, adopted 29 May 2013, CRC/C/GC/14. Available online: https://tbinternet.ohchr.org/_layouts/15/treatybodyexternal/ Download.aspx?symbolno=CRC $\% 2 \mathrm{fC} \% 2 \mathrm{fGC} \% 2 \mathrm{f} 14 \& \mathrm{Lang}=\mathrm{en}$ (accessed on 22 February 2020).

United Nations Committee on the Rights of the Child. 2015. Treaty-Specific Guidelines Regarding the Form and Content of Periodic Reports to be Submitted by States Parties under Article 44, Paragraph 1 (b), of the Convention on the Rights of the Child. $55^{\text {th }}$ Session, adopted 25 November 2010, CRC/C/58/Rev.2. Available online: https://tbinternet.ohchr.org/_layouts/15/treatybodyexternal/Download.aspx?symbolno=CRC $\% 2 \mathrm{fC} \%$ 2f58\%2fREV.3\&Lang=en (accessed on 15 March 2020).

United Nations Committee on the Rights of the Child. 2020. The Committee on the Rights of the Child Warns of the Grave Physical, Emotional and Psychological Effect of the COVID-19 Pandemic on Children and Calls on States to Protect the Rights of Children. Available online: https://tbinternet.ohchr.org/Treaties/CRC/Shared\% 20Documents/1_Global/INT_CRC_STA_9095_E.pdf (accessed on 11 April 2020).

United Nations General Assembly. 2003. Investigation into Sexual Exploitation of Refugees by Aid Workers in West Africa, Resolution Adopted by the General Assembly. New York: UN General Assembly.

United Nations General Assembly. 2015. Transforming Our World: The 2030 Agenda for Sustainable Development, Resolution Adopted by the General Assembly on 25 September 2015. Available online: https://undocs.org/A/ RES/70/1 (accessed on 28 March 2020).

United Nations High Commissioner for Refugees \& Save the Children UK. 2002. Sexual Violence and Exploitation: The Experience of Refugee Children in Liberia, Guinea and Sierra Leone. Available online: https://www.parliament.uk/documents/commons-committees/international-development/2002Report-of-sexual-exploitation-and-abuse-Save\%20the\%20Children.pdf (accessed on 15 February 2020).

United Nations Human Rights Office of the High Commissioner. 2020. Status of Ratification Interactive Dashboard; Geneva: United Nations Human Rights Office of the High Commissioner, April 9. Available online: https://indicators.ohchr.org/ (accessed on 10 April 2020).

United Nations Secretariat. 2003. Secretary-General's Bulletin, Special Measures for Protection from Sexual Exploitation and Sexual Abuse. Available online: https://undocs.org/pdf?symbol=en/ST/SGB/2003/13 (accessed on 29 March 2020).

USAID. 2015. Policy/Guidance on the Implementation of USAID Child Safeguarding Standards. Available online: https://www.usaid.gov/sites/default/files/documents/1864/200mbt.pdf (accessed on 3 March 2020).

Viola de Azevedo Cunha, Mario. 2017. Child Privacy in the Age of Web 2.0 and 3.0: Challenges and Opportunities for Policy; (No. 2017-03; Innocenti Discussion Paper). Florence: UNICEF Office of Research. Available online: https://www.unicef-irc.org/publications/pdf/Child_privacy_challenges_opportunities.pdf (accessed on 14 February 2020).

Walker-Simpson, Karen. 2017. The Practical Sense of Protection: A Discussion Paper on the Reporting of Child Abuse in Africa and whether International Standards Actually Help Keep Children Safe: The Practical Sense of Protection. Child Abuse Review 26: 252-62. [CrossRef]

Zarnegar Deloffre, Maryam. 2016. Global accountability communities: NGO self-regulation in the humanitarian sector. Review of International Studies 42: 724-47. [CrossRef]

(C) 2020 by the authors. Licensee MDPI, Basel, Switzerland. This article is an open access article distributed under the terms and conditions of the Creative Commons Attribution (CC BY) license (http://creativecommons.org/licenses/by/4.0/). 